\title{
Relationship between Core Self-Evaluation and Academic Procrastination among Female Students in Saudi Arabia
}

\author{
Wasantha Rajapakshe \\ Department of Business Management, SLIIT Business School, Sri Lanka Institute of \\ Information Technology, Malabe, Sri Lanka.
}

Received: June 27, 2018 Accepted: July 13, 2018 Online published: July 18, 2018

doi:10.5296/ijhrs.v8i3.13397ＵRL: https://doi.org/10.5296/ijhrs.v8i3.13397

\begin{abstract}
Four personality traits of core self-evaluation are used to describe human character and their behavior. Personality comes from within the person and remains consistent throughout his or her life. Therefore, many research papers and academic studies were carried out to understand personality and its connection to academic related behavior. This study is examined the relationship between personality dimensions and academic procrastination. This is a survey research primarily rely on data collected from undergraduate students. For this research, female undergraduates from Universities in Saudi Arabia were selected. To select the sample, three private universities are selected from the eastern province randomly and then 160 students randomly chosen for the test. The data collection is conducted by using online survey website that is only given to the selected students. The dependent variable in the analysis is the measure of academic procrastination of female Saudi students in private universities and independent variables are four personality traits defined under the core self-evaluation; self-esteem, locus of control, generalized self-efficacy and emotional stability. Collected data is analysed through; mean, standard deviation, correlation, and regression analysis. The results of the study obtained proved that there is a significance negative relationship between self-esteem, generalized self-efficacy and emotional stability and students' academic procrastination behavior. Also, there was a slightly positive relationship between a locus of control and students' procrastination behavior. However, according to the regression analysis all four personality traits are significant but show negative impact on students' procrastination behavior.
\end{abstract}

Keywords: procrastination, core self-evaluation, locus of control, self-esteem, self-efficacy, emotional stability, Saudi Arabia 


\section{Introduction}

When, Kingdom of Saudi Arabia has decided to transform from oil exporting economy to knowledge economy, a large amount of funds allocated for higher education. Nearly $10 \%$ of the total fiscal budget allocated for higher education and it is steadily growing up. Number of universities has been increased and scholarships programs are introduced for a Saudi citizen to go abroad for higher education. Student enrolment has increased from 604,000 in 2005 to one and half million in 2014 (Hababi, 2015). In addition, Saudi government pays high commitment for higher education under the Saudi Arabia's 2030 vision. As a result government expects five percent growth in higher education enrollment by 2022 and around 2.5 million students (Hababi, 2015). In the year 2030, Saudi Arabia's vision is to at least five Saudi universities would be in the top 200 universities in international rankings. Saudi Arabia will help students achieve results above international averages in global education indicators (Al-Youbi, 2017).

Through the huge investment for higher education, Saudi government expect high performance from students at the university level to support for the saudization program. However, it has been recognized that students are failed to meet the expected results. Ghafour (2010) reported to the Arab News that university dropout rate is nearly 30\%. Tanielian (2017) highlighted that English Language is one of the barrier for Saudis who cannot survive in their university programs.

In 1992, Alabdulgader (as cited in Aljohani, 2016) concluded that attrition rate were 50-68\% for science majors and between $20-37 \%$ for social science majors. The study further found that students' attrition problem would cost $43 \%$ of the total Saudi higher education budget. The average retention rate for four-year programs in 2015 was $64.2 \%$ in United States for public universities and $70.2 \%$ for private universities. (American College Testing (ACT), 2015). According to the Riyadh Economic Forum in 2011 (as cited in Aljohani, 2016), students' attrition rate was $53 \%$ in community colleges and $43 \%$ in technical colleges. In addition, it was highlighted that attrition rate was around $65 \%$ in a four-year program and 35\%-50\% in two year programs in university level.

Why students attrition rate is very high or retention rate is low in Saudi Arabia. Students' retention is considered as quality and efficiency of the university. However many students decided to leave without completing their undergraduate programs.

Al-Ghnaim (2010) (as cited in Aljohani, 2016) concluded that Saudi female students' decision to leave before graduation is influenced by personal, academic and social factors. Major finding of this study further exposed that maternity and low commitment to higher education as well as getting poor academic grades also affected to their decision to leave before graduation.

Students at public universities do not pay tuition fees and receive a monthly stipend. The government also provides scholarships for about half of private university students in the country (Hamdan, 2016). However, students' dropout rate before graduation is still the same. Classroom anxiety, procrastination, laziness, personality traits could be some causes for this crucial issue. Among them procrastination is common among many of the students. 
Procrastination can be defined as unreasonable postponement of academic activities. (Simpson \& Pychyl, 2009). Individual differences in intelligence could be a cause for students' academic procrastination.

When, students delay in completing academic work and submitting assignments in last minutes considered as an academic procrastination. It is a common problem and consequences are lower level of learning and academic achievement of university students. Finally, it can be lead to academic burnout as well as higher attrition rate. This is a critical issue which is required to be addressed, because if procrastination became students' habitual behavior, that can seriously impact their ability to be productive.

Many of the previous research discover the link between academic procrastination and academic performance and highlights that academic procrastination is negatively related to academic performance (Akinsola, Tella, \& Tella, 2007). Anxiety, dishonest behavior in the examinations, last minutes submission of assignments, mental stress also can be a result of academic procrastination (Solomon \& Rothblum, 1984).

The findings of the previous studies disclosed that the reports of students' procrastination specify a negative change with their academic performance. As a result, students can be disappointed and leave before completing the program (Goroshit, 2018).

To identify reasons for students' procrastination relate with individual differences, studies are needed to conduct. Objective of this study is to discover the relationship between academic core self-evaluation and academic procrastination among Saudi female students.

\subsection{Problem Identification}

For years, researchers have been analyzing personality traits, and its relation on students' academic procrastination. Moreover, it is important to identify whether personality does affect students with low and high academic procrastination. Personality traits can be measured with many types of personality traits. This study is focused on core self-evaluation. Core self-evaluation has been described as a person's estimation of themselves (Judge, Locke, Durham, \& Kluger, 1998). Many international researchers found out that there is a correlation between core self-evaluation and academic procrastination (Beswick, Rothblum, \& Mann, 1988; Mandap, 2016; Steel \& Klingsieck, 2016; Cavusoglu \& Karatas, 2017 and Ocal, 2016) etc.

\subsection{Aim of the Research}

The aim of the study was to quantitatively explore the relationship between academic core self-evaluation and academic procrastination among Saudi female students.

\section{Literature Review}

\subsection{Core Self-Evaluation}

Among varies types of personally measure core self-evaluation has become major selection by many researchers. Core self-evaluation involves basic evaluation of personal traits by individuals regarding their values and abilities. Four main personality dimensions of core 
self-evaluation are; self-esteem, locus of control, emotional stability, and general self-efficacy (Judge et al., 1998). Rosenberg (1965) defined self-esteem as an overall evaluation of one's self-worth. Generalized self-efficacy defined as one' ability to successfully perform wide range of task in wide range of environment without any hesitation (Bandura, 1977). Eysenck (1990) described emotional stability or low neuroticism as the tendency to feel calm and secure. The locus of control is defined as the belief that how far one can control life events as a result of one's own actions rather than influence or control by powerful others (Rotter, 1966). According to the core self-evaluation theory, these four characteristics together to explain an individual's judgment of value or worth that they have as a person (Judge et al., 1998).

Self-esteem is one of the most important personality trait discussed under the core self-evaluation. It is an essential characteristic for good mental health. Self-esteem explained as how individual feel about their worth or how they value by themselves (Blascovich \& Tomaka, 1991).

In general, it is an internal belief system of how individual hold about themselves. Branden (1969) explained self-esteem as a personal judgment or estimation about their emotions and feelings. There are many studies revealed the relationship between academic achievement and self-esteem. In the literature, it was mentioned that there was a positive correlation between academic achievement and self-esteem (Bankston \& Zhou, 2002; Lockett \& Harrell, 2003; Schmidt \& Padilla, 2003).

An academic locus of control is become a vital phenomenon among many psychologists. It is become an important factor which can be affects students' academic performance. For the reason of that many researchers conduct studies related to the academic locus of control and its impact on students' performance. Zaidi \& Mohsin (2013) revealed that intelligence, hard work and abilities are more important to their behavior.

Self-efficacy is defined as individual's capacity to perform given activities an any given time (Bandura, 1997). Generality can be defined as "efficacy beliefs associated with one activity can be generalized to similar ones within the same activity domain or across a range of activities" (Holladay \& Quinones, 2003, p. 1094). Therefore, generalized self-efficacy is more important to discuss its relationship with students' personality. How is it contributed to students' performance? Zimmerman (1995) in his study found out that Self-efficacy contribute to determination of learning tasks, and to expect and actual performance of learning tasks. Bandura (1997) proposes that self-efficacy also have an emotional impact of behaviors. People are more likely to perform tasks for which they have high self-efficacy and avoid those for which their self-efficacy is low.

Emotional stability is recognized as main individual and psychological characteristics that determine the stability of individual behavior. If students are stable in their emotions, academic achievements given a successful result. Especially when, students are in a stressful situation in their studies, emotional stability is affect the success of their performance. Valiente, Swanson, \& Eisenberg, (2012) revealed that the academic attention is largely focused on emotional stability of students. Currently many academic staff may more attention 
to give knowledge to the students rather than identified students' emotions. This would cause nervousness, anxious, frustration, depression and finally students might not be emotional stable. This type of mental instability influence students' academic achievement negatively. Teenagers who are entered into university might be characterized by negative emotions such as fear, worry, distress and anger because of new academic environment. Therefore, emotional stability can be finally leading them to leave the program before completing.

Chamorro-Premuzica, \& Furnhamb, (2008) revealed that core self-evaluation has a negative impact on students' examination anxiety. Rosopa \& Schroeder (2009) highlighted that core self- evaluation can impact on students' academic performance. Silvar (2001) and Yang \& Farn (2005) in their study found out that self-efficacy, locus of control, and self-esteem can significantly influence an academic burnout.

\subsection{Procrastination}

Academic procrastination is defined as a tendency to unnecessarily delay academic-related activities. Irrespective of age, whether school students' or college students' academic procrastination seems to be a common scenario. Procrastination behavior is regular practice for many college students nowadays. Schraw, Wadkins, \& Olafson, (2007) revealed that nearly $70 \%$ of university students concede that they procrastinate very often.

When, students are overloaded with many academic related activities this type of academic procrastination can be placed. Those overloads might be caused undue stress or anxiety upon individuals as they unable to meet deadlines and complete assignments. Negative impact of academic procrastination can be led to their psychological well-being as well as relationship with others. When they fail to meet deadlines and commitments, relationships become strained. However, many scholars have a different opinion about procrastination and its impact on an academic dropout.

Procrastination can be defined as the habitual practice of postponing or delaying, activities which necessity to complete quickly. Cambridge English dictionary (2018) defined procrastination as "to keep delaying something that must be done, often because it is unpleasant or boring". Solomon \& Rothblum (1984) defined procrastination as a wide range, from delaying beginning or completing an action, to delaying continuing an action because of a mental disorder. Procrastination became a serious problem among many university students in modern world.

In the literature can be identified various types of procrastinations; academic, every day, arousal seeking, decisional, and behavioral-avoidant procrastination. Effert \& Ferrari (1989) identified decisional procrastination. Ferrari (1992) in his research reveals that arousal and avoidance procrastination inventories and Ferrari (1994) identified Dysfunctional procrastination and its relationship with self-esteem. Milgram, Sroloff, \& Rosenbaum (1988) highlighted that procrastination of everyday life and Solomon and Rothblum (1984) identified academic procrastination.

Solomon \& Rothblum (1984) defined academic procrastination as homework finishing, readiness for the examinations or term papers submission at the endpoint of the dead line. 
They further stressed that feeling of psychological distress effect on their procrastinating behavior. The cognition component of the attitude became a major cause of their behavior. Howell \& Watson (2007) in research entitled that academic procrastination has a negative impact on students' goal orientation.

Goroshit (2018) examined relations between academic procrastination, online course participation, and academic achievement. The study results exhibited that there was a negative correlation between academic procrastination with final examination grades and similarly with the online course participations.

Balkis (2013) examined intermediary role of academic procrastination, with academic life satisfaction and academic achievement. The result of the study showed that academic procrastination has become a mediator for academic life satisfaction and academic achievement.

Beswick, Rothblum, \& Mann (1988) highlighted that there is a significant negative correlation between students' term papers and the academic procrastination behaviors and again a significant negative correlation between students' scores in the final examination and the academic procrastination behaviors. In summary, it can be explained as there is a negative correlation between procrastination behaviors and academic achievements of the students.

Ocal (2016) research is related to find out relationship between a burnout, academic self-efficacy and academic success with procrastination and students' life satisfaction. The result of the research shows that there is a significant correlation between an academic burnout, academic self-efficacy and academic success and academic procrastination. Cavusoglu \& Karatas (2017) in their study revealed that academic procrastination has a correlation with students' motivation and their psychological needs. Also, students' motivation can be predicted by basic psychological needs. Steel \& Klingsieck (2016) highlighted that there is a correlation between personality traits and academic procrastination.

Mandap (2016) examined the relationship between procrastination behaviors of the students and gender, academic courses, level of performance and level of academic self-efficacy. The result of the study highlighted that Students with low perceived academic self-efficacy showed significantly higher procrastination scores than those with high self-efficacy.

\section{Research Design and Sample Procedure}

This research is survey research primarily rely on data collected from undergraduate students. For this research, female undergraduates from Universities in Saudi Arabia were selected. To select the sample, three private universities were selected from the eastern province randomly and then 160 students randomly chosen for the test.

\subsection{Research Instrument}

The questionnaire was conducted by using online survey website that was only given to the selected students. The students were asked to answer two parts, the first part was personal questions and the second part was questions related to core self-evaluation and academic procrastination. To measure academic procrastination, lay's academic procrastination scale 
was used (Lay, 1986). Cronbach's alpha scale was 0.71 for academic procrastination.

Four basic components of the core self-evaluation were measured separately. To measure locus of control Trice's academic locus of control survey instruments was used (Trice, 1985). Cronbach's alpha scale was 0.76. This instrument is variation to Rotter's original Locus of Control survey (Yemen \& Clawson, 2003). Schwarzer \& Jerusalem's (1995) generalized self-efficacy scale was used to measure self-efficacy of the students. Cronbach's alpha scale was 0.86. Heatherton \& Polivy (1991) self-esteem questionnaire was used to scale self-esteem of the selected sample. To measure neuroticism NEO-FFI personality inventory was used (Costa \& McCrae, 1992). Cronbach's alpha scale was 0.84 .

The reliability of the questionnaire was tested using Cronbach's Alpha. All independent and dependent variables which, were included in the questionnaire, were derived from the review literature to maintain the validity of the study. A number of scholars have proved the content validity of the measurement, which has been selected for this study. Many variables in this study are concepts or factors with multiple attributes or qualities, and composite indexes have been used as measures of these variables. Consequently, some measurement scales have been adopted with modifications, while others are developed based on the underlying concepts found in previous studies. It is important that the validity and reliability of these measurement scales be evaluated to determine the appropriateness.

\subsection{Data Analysis}

The dependent variable in the analysis is the measure of academic procrastination of female Saudi students' in private universities and independent variables are four personality traits defined under the core self-evaluation; self-esteem, locus of control, generalized self-efficacy and emotional stability. Collected data was analyzed through; mean, standard deviation, correlation and ANOVA and multiple regression analysis. This study mainly focuses on impact of independent variables on dependent variable. All independent and dependent variables were measured on an interval scale to find out linear relationship between predictor and predicted variables. Pearson correlation coefficient is calculated to determine relationship among variables. Statistical Package for Social Science (SPSS) were used to analyses these quantitative method.

The equation for multiple regression is:

$\mathrm{AP}=\mathrm{a}+\beta 1 \mathrm{SE}+\beta 2 \mathrm{LC}+\beta 3 \mathrm{ES}+\beta 4 \mathrm{SF}+\mathrm{e}$.

Where, $\mathrm{AP}=$ Academic Procrastination

$$
\begin{aligned}
& \mathrm{SE}=\text { Self-Esteem } \\
& \mathrm{LC}=\text { Locus of Control } \\
& \mathrm{ES}=\text { Emotional Stability) and } \\
& \mathrm{SF}=\text { Self-Efficacy }
\end{aligned}
$$




\section{Results of the Study}

In this section, relationship among variables presented first and then impact of the independent variables: four personality traits of the core self-evaluation and dependent variable; procrastination is presented. A total of 160 students were taken part in this study. All these are young women age in between 19-25 with a mean age of 23.68 and standard deviation with 0.98 years. All students were selected from business faculties among three universities.

Result of the correlation analysis and descriptive statistics are presented in the Table 1. Correlation coefficient evidently shows negative relationship between procrastination and self-esteem $(r=-.085, \mathrm{p}<0.05)$, emotional stability $(r=-.160, \mathrm{p}<0.05)$, and academic self-efficacy $(r=-.132, \mathrm{p}<0.05)$, and positive but lower level relationship between procrastination and locus of control $(r=.002, \mathrm{p}<0.05)$. This clearly shows that students' behavior related to procrastination is depended on their individual personality traits. When they have lower level core self-evaluation, academic procrastination is getting increase. As a result their academic performance getting worst and ultimate result is frustration and consequently high dropout rate among them.

Table 1. Descriptive Statistics and Correlation Matrix

\begin{tabular}{l|c|c|c|c|c|c|c}
\hline & Mean & $S D$ & 1 & 2 & 3 & 4 & 5 \\
\hline 1. Procrastination & 15.08 & 6.28 & --- & & & & \\
\hline 2. Self-Esteem & 11.39 & 5.62 & -.085 & --- & & & \\
\hline 3. Locus of Control & 10.45 & 4.46 & .002 & .080 & --- & & \\
\hline 4. Emotional Stability & 10.89 & 6.20 & -.160 & -.261 & .075 & --- & \\
\hline 5. Self-Efficacy & 11.02 & 0.48 & -.132 & .227 & .207 & -.187 & --- \\
\hline
\end{tabular}

$\mathrm{N}=160$

$* \mathrm{p}<.05$

In addition, the Table 1 shows, emotional stability has negative correlation with self-esteem ( $\mathrm{r}$ $=-.261, \mathrm{p}<0.05)$, and self-efficacy $(\mathrm{r}=-.187, \mathrm{p}<0.05)$, while, positive relationship with locus of control $(\mathrm{r}=.075, \mathrm{p}<0.05)$. This indicates that among personality traits, emotional stability affect negatively their self-esteem and self-efficacy. If student are stable in their emotions it might be affected to weak their self-esteem and self-efficacy traits.

Table 2. Model Summary of Regression Analysis

\begin{tabular}{l|l|l|l|ll}
\hline Model Summary & \multicolumn{5}{l}{} \\
\hline Model & $\mathrm{R}$ & R Square & Adjusted R Square & $\begin{array}{l}\text { Std. Error of the } \\
\text { Estimate }\end{array}$ \\
\hline 1 & $.762^{\mathrm{a}}$ & .602 & .600 & 3.180 \\
\hline \multicolumn{7}{l}{ a. Predictors; (Constant), Core Self-evaluation } \\
\hline
\end{tabular}

Table 2 shows the coefficient of determination, $\mathrm{R}^{2}$, is .602 . The interpretation is that core self-evaluation explains 60 percent of the variance in students' academic procrastination at the .05 level of significance. This indicates higher prediction ability for explanations 
academic procrastination by core self-evaluation. The remains are influenced by other variables other than the variables not include in this study, such as difficulty of the program, nature of the assignment, number of assignment and other activities, lecturers' behavior, facilities of the academic environment etc. The correlation coefficient of $\mathrm{R}$ is .762. This value can be changed with the influence of students' personality traits of core self-evaluation; self-esteem, locus of control, emotional stability and self-efficacy collectively to their academic procrastination.

To explain the causal relationship between academic procrastination and four dimensions of core self-evaluation multiple regression analysis was used. The results of the multiple regression analysis are presented in Table 3 and 4.

Table 3. The Results of ANOVA

ANOVA $^{\mathrm{a}}$

\begin{tabular}{l|l|l|l|l|l|l}
\hline \multicolumn{6}{l}{ Results of ANOVA } \\
\multicolumn{2}{l}{ Model } & $\begin{array}{l}\text { Sum of } \\
\text { Squares }\end{array}$ & Df & Mean Square & F & Sig. \\
\hline 1 & Regression & 772.810 & 5 & 154.877 & 51.643 & $.000 \mathrm{~b}$ \\
& Residual & 470.516 & 155 & 2.888 & & \\
& Total & 1243.326 & 160 & & & \\
\hline
\end{tabular}

a. Dependent Variable: Procrastination

b. Predictors; (Constant), Core Self-evaluation

Table 3 shows the value of F-test $(51.643, \mathrm{p}<0.000)$, which indicated that the model is good fit for the data. $\mathrm{P}$ values is .000 shows that the model is significant.

Table 4. The Results of Multiple Regression Analysis

Coefficients $^{\mathrm{a}}$

\begin{tabular}{l|l|l|c|c|c}
\hline \multirow{2}{*}{ Model B } & \multicolumn{2}{|l|}{$\begin{array}{l}\text { Unstandardized } \\
\text { coefficients }\end{array}$} & $\begin{array}{l}\text { Standardized } \\
\text { coefficients }\end{array}$ & \multirow{2}{*}{ T } & \multirow{2}{*}{ Sig. } \\
\cline { 2 - 4 } & B & Std. Error & Beta & & \\
\hline (Constant) & 1.435 & 47.104 & & 1.32 & 0.000 \\
Self-Esteem & -.245 & .223 & .134 & 2.85 & 0.001 \\
Locus of Control & -.237 & .172 & .089 & -2.76 & 0.001 \\
Emotional Stability & -.279 & .257 & .198 & 3.28 & 0.021 \\
Self-Efficacy & -.140 & .256 & .204 & -1.89 & 0.000 \\
\hline
\end{tabular}

a. Dependent Variable: Academic Procrastination

Table 4 shows the results of regression analysis. It shows that all significance $p$ values of the variables are less than 0.05 . Thus, all four personality traits of students' core self-evaluation are significantly influence on students' academic procrastination at the 0.05 level of significance. This means that self- esteem, locus of control, emotional stability and academic self-efficacy significantly effects with the academic procrastination. It is clearly indicated that students' personality traits directly related with their procrastination behavior.

The t-value for each individual regression coefficient in the model is stated to assess whether the self-esteem, locus of control, emotional stability and self-efficacy are a significant 
predictor of the students' procrastination behavior. The result of the t-values shows that self-esteem $(\mathrm{t}=2.85 ; \mathrm{p}=.001<.05)$; locus of control $(\mathrm{t}=-2.76 ; \mathrm{p}=.001<.05)$; emotional stability $(\mathrm{t}=3.28 ; \mathrm{p}=.021<.05)$; and self-efficacy $(\mathrm{t}=-1.89 ; \mathrm{p}=.000<.05)$ are significant at 0.05 level.

Further, Table 4 shows, the result of correlation coefficient of self-esteem and procrastination $(\beta=-.245, p<.001)$, locus of control and procrastination $(\beta=-.237, p<.001)$, emotional stability and procrastination $(\beta=-.279, \mathrm{p}<.021)$ and self-efficacy and procrastination $(\beta=$ $-.140, \mathrm{p}<.000)$, were significant and negative.

The resulting regression equation is;

$$
\begin{gathered}
\mathrm{AP}=\mathrm{a}+\beta 1 \mathrm{SE}+\beta 2 \mathrm{LC}+\beta 3 \mathrm{ES}+\beta 4 \mathrm{SF}+\mathrm{e} \\
\mathrm{AP}=47.104+-.245 \mathrm{SE}+-.237 \mathrm{LC}+-.279 \mathrm{ES}+-.140 \mathrm{SF}+\mathrm{e}
\end{gathered}
$$

$\mathrm{R}^{2}$ values are respectively, $0.223,0.172,0.257$ and 0.256 for self-esteem, locus of control, emotional stability and self-efficacy are shown in Table 4 . The personality type of self-esteem has significantly explained $22 \%$ of variance in procrastination. The locus of control and emotional stability have an ability to explain $17 \%$ and $25 \%$ variance of academic procrastination respectively. The academic self-efficacy has significantly explained 25\% variance in students' academic procrastination. Concluding from the tables of the correlation test and the regression analysis, students' personality affect or it has significance negative impact on their academic procrastination.

\section{Discussion and Conclusion}

Four personality traits of core self-evaluation are used to describe human character and their behavior. Personality comes from within the person and remains consistent throughout his or her life. Therefore, many research papers and academic studies were carried out to understand personality and its connection to academic related behavior.

This study aimed to identify personality dimensions of core self-evaluation and students' procrastination behavior. The study examined the relationship between personality dimensions and academic procrastination. Also, the four dimensions of core self-evaluation were used: self-esteem, locus of control, emotional stability and academic self-efficacy.

The result of the correlation analysis shows that significant negative relationship with self-esteem, emotional stability and academic self-efficacy and academic procrastination. This result matched with the finding of Seo (2008); Saddler \& Buley (1999); Busko (1998); and Alexandros, Christos, \& Konstantinos (2013) studies. The result of the study shows that students' personality traits are affective factor to predictor of procrastination inversely is a significant factor of academic achievement. When students' academic procrastination is high, they show poor performance in their academic program and final result is quit from the program without competing their degrees. As explained by Akinsola et al. (2007) given similar circumstances, academic procrastination might negative result of academic performance. 
Beck, Koons, \& Milgrim (2000) discovered that students with internal control reduced students' procrastination behavior. Ferrari, (2001) revealed that students' performance depend on procrastination. Especially chronic procrastinators' performance reduce when they are work under pressure. This result is consistence with the finding of the current study. It shows that locus of control has slightly positive relationship with students' procrastination behavior.

Weiner (1994) indicated that students' self-respect is related to academic accomplishment. It means students' academic performance would be increased if they have their self-esteem. This result is consistence with the results of the current study. The current study shows that negative correlation between self-esteem and procrastination behavior. If students' self-esteem is high, the procrastination behavior will be decreased and improve academic performance. This result is consistent with Ferrari (1994) findings. According to the Ferrari, procrastinating behavior of the students is supported by the self-respect.

Other research findings consistence with the current study is Howell \& Watson's (2007) research findings. Howell \& Watson (2007) highlighted that significant negative correlation between procrastination and student's academic control. According to the Weiner's (1994) attribution theory, the controllability of the reason is function of personal responsibility. If reason is controllable, individual by themselves can control their behavior. The current study revealed that core self-evaluation is significantly impact the students' procrastination. This result is consistent with the Weiner's attribution theory. According to the theory, when students' control their behavior, they can change consequences of their behavior.

Finally, this study reveal that correlation among four traits of the core self-evaluation. It shows negative correlation between self-esteem and self-efficacy with emotional stability. In other words, if students' emotional stability is stable, they can control the situation. This is proved by the study of Judge, et al., 1998.

In conclusion, the results obtained proved that there was a significance negative relationship between three personality traits; self-esteem, self-efficacy and emotional stability and student academic procrastination behavior. Also, there was a slightly positive relationship between locus of control and student procrastination behavior. However, according to the regression analysis it was significant but shows negative impact on all four personality traits.

The findings of this study established that students who has higher level of academic procrastination experienced poor academic results. Their procrastination behavior is depending on their personality traits. Given the findings of the current study, it is recommended that university academic staff should identify students' procrastination behavior, and they should facilitate to improve students' personality traits. It will improve students' academic performance and when they satisfied with their performance it will lead to decrease students' dropout rate.

One of the limitations of this study was sample. It was limited only female students in three private universities. It will not support to generalize the findings of the study. In addition, the study was limited to quantitative analysis only. In spite of these limitations, study would like to suggest that future research study has to focus on the relationship between procrastination 
with other variables as well as a large sample.

\section{References}

American College Testing (ACT). (2015). National Collegiate Retention and Persistence-to-Degree Rates, ACT Institutional Data File, 5-6. [Online] Available: https://www.act.org/content/dam/act/unsecured/documents/retain_2015.pdf) (June 22, 2018).

Akinsola, M. K., Tella, A., \& Tella, A. (2007). Correlates of academic procrastination and mathematics achievement of university undergraduate students. Eurasia Journal of Mathematics. Science and Technology Education, 3(4), 363-370. https://doi.org/10.12973/ejmste/75415

Alexandros, G. S., Christos, C. F., \& Konstantinos, C. F. (2013). The relationship between personality type and academic performance. The case of Greek university's student. Proceeding of the 3rd International Conference: Quantitative and Qualitative Methodologies in the Economics and Administrative Sciences, Athens, Greece, p. 333-344. [Online] Available: https://www.academia.edu/3638543/the_relationship_between_personality_type_and_acade mic_performance._the_case_of_greek_universitys_students_2013 (June 22, 2018).

Aljohani, O. (2016). Analyzing the Findings of the Saudi Research on Student Attrition in Higher Education. International Education Studies, 9(8). [Online] Available: http://dx.doi.org/10.5539/ies.v9n8p184 (June 22, 2018). https://doi.org/10.5539/ies.v9n8p184

Al-Youbi, A. O. (2017). The development and advancement of higher education in Kingdom of Saudi Arabia, QS Asia News Network, [Online] Available:http://qswownews.com/higher-education-in-saudi-arabia/ (June 22, 2018).

Balkis, M. (2013). Academic procrastination, academic life satisfaction and academic achievement: The mediation role of rational beliefs about studying, Journal of Cognitive and Behavioral Psychotherapies, 13(1), 57-74.

Bandura, A. (1977). Self-efficacy: Toward a unifying theory of behavioral change. Psychological Review, 84(2), 191-215. https://doi.org/10.1037/0033-295X.84.2.191

Bandura, A. (1997). Self-Efficacy: e Exercise of Control. New York: Freeman.

Bankston, C. L., \& Zhou, M. (2002). Being Well vs. Doing Well: Self-Esteem and School Performance among Immigrant and Nonimmigrant Racial and Ethnic Groups, International Migration Review, 36(2), 389 - 415. https://doi.org/10.1111/j.1747-7379.2002.tb00086.x

Beck, B., Koons, S., \& Milgrim, D. (2000). Correlates and consequences of behavioral procrastination: The effects of academic procrastination, self-consciousness, self-esteem, and self-handicapping. Journal of Social Behavior and Personality, 15, 3-13.

Beswick, G., Rothblum, E. D., \& Mann, L. (1988). Psychological antecedents of student procrastination. Australian psychologist, 207-217. https://doi.org/10.1080/00050068808255605 
Blascovich, J., \& Tomaka, J. (1991) Measures of self-esteem. Measures of Personality and Social Psychological Attitudes, Scientific Research, 1, 115-160. https://doi.org/10.1016/B978-0-12-590241-0.50008-3

Branden, N. (1969). The Psychology of Self-Esteem. New York: Bantam. p.139.

Busko, D. A. (1998). Causes and consequences of perfectionism and procrastination: A structural equation model. Unpublished master's thesis, University of Guelph, Canada. [Online] Available:

http://citeseerx.ist.psu.edu/viewdoc/download?doi=10.1.1.456.4450\&rep=rep1\&type=pdf (June 22, 2018).

Cambridge English Dictionary. (2018). Cambridge University Press, UK. [Online] Available: https://dictionary.cambridge.org/dictionary/english/procrastination. (June 22, 2018).

Cavusoglu, C., \& Karatas, H. (2017) Academic Procrastination of Undergraduates: Self-determination Theory and Academic Motivation, The Anthropologist, 20(3), 735-743, https://doi.org/10.1080/09720073.2015.11891780

Chamorro, P. T., \& Furnhamb, A. (2008), Personality, intelligence and approaches to learning as predictors of academic performance, Personality and Individual Differences, 44(7), 1596-1603. https://doi.org/10.1016/j.paid.2008.01.003

Costa, P. T., \& McCrae, R. R. (1992). Revised NEO Personality Inventory (NEO-PI-R) and NEO Five-Factor Inventory (NEO-FFI) professional manual. Odessa, Florida: Psychological Assessment Resources.

Effert, B., \& Ferrari, J. R. (1989). Decisional procrastination: Examining personality correlates. Journal of Social Behavior and Personality, 4, 151-156.

Eysenck, H. J. (1990). Biological dimensions of personality. In L. A. Pervin (Eds.), Handbook of personality: Theory and research, (pp. 244-276). New York: Guilford.

Ferrari, J. R. (1992) Psychometric validation of two procrastination inventories for adults: Arousal and avoidance measures. Journal of Psychopathology and Behavioral Assessment, 14, 97-110. https://doi.org/10.1007/BF00965170

Ferrari, J. R. (1994). Dysfunctional procrastination and its relationship with self-esteem, interpersonal dependency, and self-defeating behaviors. Personality and Individual Differences, 17, 673-679. https://doi.org/10.1016/0191-8869(94)90140-6

Ferrari, J. R. (2001). Procrastination as self-regulation failure of performance: Effects of cognitive load, self-awareness, and time limits on 'working best under pressure". European Journal of Personality, 15(5), 391-406. https://doi.org/10.1080/10852352.2016.1198157

Ghafour, P. K. A. (2010). University dropout rate 30 percent, Arab News, [Online] Available: http://www.arabnews.com/node/349946 (June 22, 2018). 


\section{Macrothink Institute ${ }^{\mathrm{TM}}$}

Goroshit, M. (2018). Academic procrastination and academic performance: An initial basis for intervention, Journal of Prevention \& Intervention in the Community, 46(2), 131-142. http://dx.doi.org/10.1080/10852352.2016.1198157

Habibi, N. (2015). Is Saudi Arabia training too many graduates? University World News, 376. [Online] Available: http://www.universityworldnews.com/article.php?story=20150714013422488(June 22, 2018).

Hamdan, A. (2016). Reforming higher education in Saudi Arabia: Reasons for optimism. In F. Badry, \& J. Willoughby, J. (Eds.), Higher education revolutions in the Gulf: Globalization and institutional viability, (pp.153-177). New York, Routledge, Taylor \& Francis Group.

Heatherton, T. F., \& Polivy, J. (1991). Development and validation of a scale for measuring state selfesteem. Journal of Personality and Social Psychology, 60, 895-910. https://doi.org/10.1037/0022-3514.60.6.895

Holladay, C. L., \& Quiñones, M. A. (2003). Practice Variability and Transfer of Training: The Role of Self-Efficacy Generality. Journal of Applied Psychology, 88(6), 1094-1103. https://doi.org/10.1037/0021-9010.88.6.1094

Howell, A., \& Watson, D. (2007). Procrastination: Associations with achievement goal orientation and learning strategies. Person Individual Differences, 43, 167-78. https://doi.org/10.1016/j.paid.2006.11.017

Judge, T. A., Locke, E. A., Durham, C. C., \& Kluger, A. N. (1998). Dispositional effects on job and life satisfaction: The role of core evaluations. Journal of Applied Psychology, 83, 17-34. https://doi.org/10.1037/0021-9010.83.1.17

Lay, C. (1986). At last, my research article on procrastination. Journal of Research in Personality, 20, 474-495. https://doi.org/10.1016/0092-6566(86)90127-3

Lockett, C. T., \& Harrell, J. P. (2003). Racial Identity, Self-Esteem, and Academic Achievement: Too Much Interpretation, Too Little Supporting Data, Journal of Black Psychology, 29(3), 325-336. https://doi.org/10.1177/0095798403254216

Mandap, C. M. (2016). Examining the Differences in Procrastination Tendencies among University Students, International Journal of Education and Research, 4(4) 431.

Milgram, N. A., Sroloff, B., \& Rosenbaum, M. (1988). The procrastination of everyday life. Journal of Research in Personality, 22, 197-212. https://doi.org/10.1016/0092-6566(88)90015-3

Ocal, K. (2016). Predictors of academic procrastination and university life satisfaction among Turkish sport schools students, Educational Research and Reviews, 11(7), 482-490. https://doi.org/10.5897/ERR2016.2645

Rosenberg, M. (1965). Society and the adolescent selfimage. Princeton, New Jersey: Princeton University Press. p. 3-6. https://doi.org/10.1515/9781400876136 
Rosopa, P. J., \& Schroeder, A. N. (2009). Core self-evaluations interact with cognitive ability to predict academic achievement. Personality and Individual Differences, 47, 1003-1006. https://doi.org/10.1016/j.paid.2009.07.028

Rotter, J. B. (1966). Generalized expectancies for internal versus external control of reinforcement. Psychological Monographs, 80(1) (Whole No. 609). [Online] Available: https://pdfs.semanticscholar.org/161c/b7ac92d7571042bb11ebdaaa1175be8079f8.pdf (June 22, 2018).

Saddler, C. D., \& Buley, J. (1999). Predictors of academic procrastination in college students. Psychological Reports, 84(2), 686-688. https://doi.org/10.2466/PR0.84.2.686-688

Schmidt, J. A., \& Padilla, B. (2003). Self-Esteem and Family Challenge: An Investigation of Their Effects on Achievement. Journal of Youth and Adolescence, 32(1), 37-46. https://doi.org/10.1023/A:1021080323230

Schraw, G., Wadkins, T., \& Olafson, L. (2007). Doing the things we do: A grounded theory of academic procrastination. Journal of Educational Psychology, 99, 12-25. https://doi.org/10.1037/0022-0663.99.1.12

Schwarzer, R., \& Jerusalem, M. (1995). Generalized Self-Efficacy scale. In J. Weinman, S. Wright, \& M. Johnston (Eds.), Measures in health psychology: A user's portfolio. Causal and control beliefs, (pp. 35-37). Windsor, UK: Nfer-Nelson.

Seo. (2008). Self-efficacy as a Mediator in the Relationship between Self-oriented Perfectionism and Academic Procrastination. Social Behavior and Personality, 36(6), 753-764. https://doi.org/10.2224/sbp.2008.36.6.753

Simpson, W. K., \& Pychyl, T. A. (2009). In search of the arousal procrastinator: Investigating the relation between procrastination, arousal-based personality traits and beliefs about procrastination motivations. Personality and Individual Differences, 47, 906-911. https://doi.org/10.1016/j.paid.2009.07.013

Slivar, B. (2001). The syndrome of burnout, self-image, and anxiety with grammar school students. Horizons Psychology, 10, 21-32.

Solomon, L. J., \& Rothblum, E. D. (1984). Academic procrastination: frequency and cognitive behavioral correlates. Journal of Counseling Psychology, 31(4), 503-509. https://doi.org/10.1037/0022-0167.31.4.503

Steel, P., \& Klingsieck, K. B. (2016). Academic Procrastination: Psychological Antecedents Revisited, Australian Psychologist, 51(1), 36-46. https://doi.org/10.1111/ap.12173

Tanielian, A. R. (2017). Foreign language anxiety among first-year Saudi university students, The International Education Journal: Comparative Perspectives, 16(2). 116-130. [Online] Available: http://openjournals.library.usyd.edu.au/index.php/IEJ/index (June 22, 2018).

Trice, A. D. (1985). An academic locus of control scale for college students. Perceptual and Motor Skills. https://doi.org/10.2466/pms.1985.61.3f.1043 


\section{Macrothink}

International Journal of Human Resource Studies

ISSN 2162-3058 2018, Vol. 8, No. 3

Valiente, C., Swanson, J., \& Eisenberg, N. (2012). Linking students' emotions and academic achievement: when and why emotions matter. Child Development Perspectives, 6, 129-135. https://doi.org/10.1111/j.1750-8606.2011.00192.x

Weiner, B. (1994). Integrating social and personal theories of achievement striving. Review of Educational Research, 164, 557-573. [Online] Available: http://citeseerx.ist.psu.edu/viewdoc/download?doi=10.1.1.908.5930\&rep=rep1\&type=pdf (June 22, 2018).

Yang, H. J., \& Farn, C. K. (2005). An investigation the factors affecting MIS student burnout in technical-vocational college. Computer Human Behavior, 21, 917-932. https://doi.org/10.1016/j.chb.2004.03.001

Yemen, G., \& Clawson, J. G. (2003). The Locus of Control, the University of Virginia Darden School Foundation, Charlottesville, VA. p.1. [Online] Available: https://faculty.darden.virginia.edu/clawsonj/General/SELF_ASSESSMENT_TOOLS/OB-786 _Locus_of_Control.pdf (June 22, 2018).

Zaidi, I. H., \& Mohsin, M. N. (2013). Locus of control in graduation students. International Journal of Psychological Research, 6(1) 15-20. https://doi.org/10.21500/20112084.695

Zimmerman, B. J. (1995). Self-efficacy and educational development. In A. Bandura (Eds.), Self-efficacy in changing societies. (pp. 202-231). New York, Cambridge University Press. https://dx.doi.org/10.1017/CBO9780511527692.009

\section{Copyright Disclaimer}

Copyright for this article is retained by the author(s), with first publication rights granted to the journal.

This is an open-access article distributed under the terms and conditions of the Creative Commons Attribution license (http://creativecommons.org/licenses/by/4.0/). 